сохранение всех подлинных элементов памятника с восстановлением утраченных конструктивных деталей и архитектурного убранства на основании результатов комплексных научных исследований объекта.

В 2016 - 2017 гг. были проведены натурные и архивные исследования. В результате этих исследований установлено, что первоначально церковь имела световой барабан, позднее закрытый куполом полусферической формы.

В архивных материалах найдены фотографии фамильного склепа.

В 2017 г. выполнены фотограмметрические обмеры церкви и колокольни. С их помощью удалось определить габариты основных объемов зданий и размеры отдельных деталей, в том числе и высоту скульптуры Архангела Михаила в завершении церкви.

На основании проведенного ландшафтно-визуального анализа центральной части села Аксиньено выявлены ценные элементы ансамбля, в котором Спасская церковь с колокольней являются основными архитектурными доминантами в объемнопространственной структуре села Аксиньино, в значительной степени утратившего свою историческую среду.

$$
* * *
$$

1. История Венёва / Венёвский уезд: сайт Дениса Махеля. URL: http://www.veneva.ru/history.html

2. Корнеева М.Е. Историко-культурное наследие Тулы и Тульской области для развития рекреации и туризма в регионе, Фундаментальные исследования / М.Е. Корнеева - М.:,2013. - № 6-6. - С. 15301534.

3. Харитонов В.С. Историко-культурное наследие Тульского края: курс лекций / В.С. Харитонов Тула: ТулГУ, 2011. - С. 12-18, С. 26-47.

\title{
Щукина И.Л. \\ Проблемы приспособления объектов культурного наследия на примере дачи К.Г. Фаберже
}

Санкт-Петербургский государственный архитектурно-строительный университет (Россия, Санкт-Петербург)

doi:10.18411/spc-22-03-2018-21

idsp: 000001:spc-22-03-2018-21

Активная работа по восстановлению памятников истории и культуры из руин велась в послевоенные годы в Санкт-Петербурге и пригородах, были восстановлены такие объекты как Екатерининский и Петергофский дворцы, а так же их территории. В настоящее время работы по ним ведутся, но основные работы выполнены[6, с. 439]. Это бывшие императорские резиденции, однако в Санкт-Петербурге и ближайших пригородах есть ряд объектов культурного наследия, которые постепенно приходят в упадок, одним из таких объектов является дача К.Г. Фаберже на Песочном шоссе.

В Левашово в 1883 г. был продан участок под дачу известному ювелиру К.Г. Фаберже. Дачу начали строить предположительно в 1901 г[5, с. 196].

Дача представляла собой двухэтажное здание, возведенное на высоком гранитном цоколе. Основной объем был квадратом в плане. Решение фасадов дома было очень характерно для модерна. Однако, начиная с 1907 г., здание дачи начинает перестраиваться по проекту архитектора Гольнбека. Согласно проекту существующая деревянная дача Шмидта сохранила свою прежнюю планировку, органически включаясь в состав вновь возводимого двухэтажного каменного здания.

Дача строилась посреди густого ельника, который стал ядром парка, окружающего дачу Фаберже. Парк имел ярко выраженный пейзажный характер. Его территория, представляющая собой естественный рельеф, не подвергалась планировке. Ельник, преобладающий в парке, был обогащен подсадкой деревьев других пород: 
дуба, липы, сосны. Живая изгородь из выстроившихся в линию елей отделяет парк от шоссе[5, с. 229]. Два могучих вяза (один из них сохранился доныне), по-видимому, обрамляли вход на его территорию. От Дибунской дороги к южному фасаду дома Фаберже ведут две аллеи: еловая и дубовая. Еловая аллея, несколько смещенная влево относительно центральной оси здания, подходит к нему вплотную. Еще левее параллельно ей была высажена дубовая аллея, завершающаяся большим дубом, расположенным на ее центральной оси и окруженным кольцом елей[4].

Красота северной природы, горы, долины и озера под Петербургом привлекают сюда все большее количество горожан. Под дачи осваиваются даже казалось бы не совсем благоприятные для строительства низменные территории. Так к началу XX века сформировался огромный дачный поселок в районе ст. Левашово по левую сторону от Финляндской железной дороги.

Дача А.К. Фаберже после отъезда его в 1918 г. за границу была приспособлена под военную казарму, а затем там располагалась военная комендатура. В 1924-1928 гг. дача находилась в ведении Левашовских военных лагерей, а в 1939-1945 гг. в ней помещались военный госпиталь, позднее детский санаторий военного ведомства. С 1953 г. она использовалась для размещения детских учреждений Академии тыла и транспорта Советской Армии. В 1989 г. дача Фаберже была принята под охрану государства. Затем была разработана проектная документация с целью использования здания под базу отдыха объединения "Реставратор". В настоящее время дача находится в распоряжении Министерства культуры России[7, с. 511].

Несомненно, дача Фаберже в Левашово представляет большой интерес, с одной стороны - как один из немногих сохранившихся образцов усадебной архитектуры модерна, а с другой стороны - как историко-культурный памятник, теснейшим образом связанный с именами знаменитого общественного деятеля архитектора И.А. Гальнбека и членов семьи Фаберже, вписавших блестящую страницу в историю ювелирного искусства в России.

Помимо основного здания загородного дома под охрану государства в 1995 г. указом Президента РФ № 176 были взяты сохранившиеся еще две постройки: конюшенный корпус и ледник, а также парк и пруд. К сожалению, в настоящее время парк находится в аварийном состоянии.

Дача Фаберже несколько раз меняла владельцев, каждому последующему она передавалась в более плачевном состоянии. Изначально каждый пользователь рьяно говорит о том, что он отреставрирует здания и приспособит к современному использованию. Но проходит время и он отказывается от объекта и все начинается заново. В результате здания стоят и не используются и превращаются в руины.

Отношения в области сохранения, использования, популяризации и государственной охраны объектов культурного наследия регулирует Федеральный закон от 25 июня 2002 года № 73-Ф3 «Об объектах культурного наследия (памятниках истории и культуры) народов Российской Федерации» (далее - Закон)[3].

Согласно Закону, под государственной охраной объектов культурного наследия понимается система мер, направленных на выявление, учёт, изучение объектов культурного наследия, предотвращение их разрушения или причинения им вреда, контроль за сохранением и использованием объектов культурного наследия. Меры предпринимаются органами: государственной власти Российской Федерации, государственной власти субъектов Российской Федерации; местного самоуправления в пределах их компетенции [6, с. 440]. 
Моя магистерская работа направлена на уточнение предметов охраны и как следствие уточнение более подходящих мер и механизмов для сохранения и приспособления дачи К.Г. Фаберже.

$$
* * *
$$

1. Этапы простанственного формирования Санкт-Петербурга: кристализация градостроительного генетического кода, единство развития и сохранения / С.В. Семенцов // Промышленное и гражданское строительство . - 22/03/2007 . - с.29

2. Богуславский, М. М. Международная охрана культурных ценностей / М. М. Богуславский. - М. : Международные отношения, 1979. - $192 \mathrm{c}$.

3. Федеральный закон от 25.06.2002 № 73-Ф3 (ред. от 07.05.2013) «Об объектах культурного наследия (памятниках истории и культуры) народов Российской Федерации» // Парламентская газета - 2002 29 июня - №120-121

4. Алексеев Л.А. Дача Фаберже в Левашово. Историческая справка. Институт «Ленпроектреставрация». Л., 1990. Архив КГИОП, Н-3138

5. Мурашова, Н. В. Дворянские усадьбы Санкт-Петербургской губернии. Всеволожский район / Н. В. Мурашова, Л. П. Мыслина. - СПб. : "Алаборг", 2008. - 320 с.

6. Проблемы приспособления объектов культурного наследия на примере ближних усадеб высшей знати/ Е.А. Козырева // РГПУ им. А.И. Герцена в VI Международной научно-практическая конференции «Природное и культурное наследие: междисциплинарные исследования, сохранение и развитие»- СПб - 2017- с. 439-441

7. Е.Л. Александрова. Северные окрестности Петербурга. Историческое прошлое/ Е.Л. АлександроваСПб.: Искусство России, 2008. - 639с. 